\title{
Contemporary Youth Subcultures: The CDA Approach
}

\author{
CHEN Min \\ China Youth University of Political Studies, Beijing, China
}

\begin{abstract}
In recent years, the cultural studies began to take a linguistic turn. This paper employed the three-dimensioned model of Fairclough, a critical discourse analysis (CDA) approach to explore youth subcultures. The cultural discourse of youth in different periods was examined in terms of discursive strategies, discursive practices, and social practices. The analysis shows that the subcultural groups adopt various discursive strategies to resist mainstream ideologies and construct the subcultural ideology and their collective identity. Meanwhile, their discursive practices build effective interaction mode within the subcultural groups. The examples of subcultures reveal that subcultures often emerge in the time of the social and cultural change and reshape the mainstream ideologies and unreasonable social structure.
\end{abstract}

Keywords: youth subcultures, critical discourse analysis, ideologies, discursive strategies, discursive practices

\section{Introduction}

Since the latter half of the 20th century, the contemporary world revived from the post-war ruins and spectacular cultures including mass culture, popular culture, consumer culture, and media culture exploded. Among others, youth subcultures, with their unique style draw great attention. Fashionable apparels, individualized music, specialized vocabulary, and rebellious minds demonstrate the unprecedented life and spiritual pursuit of the young generation. The young generation is making their era and their own cultures. Their cultural creation makes a far-reaching influence on the society, transforming the life styles of other social groups and altering the ideologies of mainstream society. The youth subculture is so vibrant that it invites the interest of the researchers all over the world and continues to be a popular topic for modern academic community.

From different perspectives, the scholars have explored the backgrounds, characteristics, and the influence of youth subcultures and their interaction with social factors. Generally speaking, the studies of youth subcultures can be divided into three traditions. The first tradition developed from the Chicago school in America, which represented a tradition of American sociology that extended from the early 20th century until the 1950s. The Chicago school employed the ethnographical approach and participatory observation to investigate the urban youth, particularly the deviant aspects of urban youth and believed that subcultures in the US arose in part as a result of urbanization and as the efforts of the deviant working class youth to gain the social capital.

Just as the Chicago school viewed the subcultures as social problems, the Birmingham school also interpreted youth subcultures from sociological perspective. The Birmingham school, the scholars associated with CCCS (Center for Contemporary Cultural Studies of Birmingham College), studied the middle-class youth

CHEN Min, lecturer, master, English Department, China Youth University of Political Studies. 
cultures in Britain in the decades following World War II. They saw the subcultures in Britain such as skinheads, mods, and punks as the symbolic form of resistance from working-class youth against cultural hegemony of the capitalist class. The scholars including Hebdige, Stanley Cohen, and Paul Willis developed concepts such as subcultural style, moral panic, commodification, etc. Their theories have been widely employed to analyze the contemporary subcultural world. However, their overemphasis on class struggle and lack of attention to ordinary youth life also brought in critique of the later scholars.

In 1990s, the cultural scholars began to saw the subcultures from post-modernist lens, and this group of scholars such as Redhead, Muggleton, and Bennet formed the post-subculturalist tradition. In this tradition, class, gender, and race became less relevant to understanding youth subcultures. The post-subculturalists criticized CCCS's subcultural studies and denied the stable collective identities of youth groups. In studying the club cultures, rave, electronic dance music, they suggested the subcultures as fluid, fragmented, decentralized scenes or neo-tribes and the subcultural participation more as "a matter of choice than a result of structurally determined social positions" (Haenfler, 2014, p. 12).

Regardless of the different strands the scholars subscribed to, subcultures are not static and isolated, but ever-changing. They reflected the response of youth to the contemporary time, space, and social dilemma faced by youth.

\section{Critical Discourse Analysis: A New Perspective of Subcultural Studies}

Critical Discourse Analysis (henceforth CDA) is an emerging research field of modern linguistic studies, which stemmed from functional linguistics. Fairclough, the leading CDA scholar, defined discourse, both the language use in speech and writing "as a form of social practice" (Fairclough, 1997, p. 258). Taking the relationship between discourse and society as its research subject, it addresses the social problems and therefore realizes the critical value of linguistic research. CDA researchers claim that discourse can reproduce social status quo and it is also shaped by of power and ideologies. Since its birth in 1970s, CDA has developed some unique research approaches and methodologies and become one of the most vibrant interdisciplinary research fields.

Due to different theoretical origins, the scholars established different approaches to CDA, mainly including Fairclough's sociocultural approach (1995a, 1995b, 2000, 2003), discourse-historical approach of the Vienna School (Reisigl \& Wodak, 2001; Wodak, 1996, 2002) and sociocognitive model of Van Dijk (1993, 1998, 2001). Among them, sociocultural approach is most widely accepted. It analyzes the relationship between discourse and wider social cultural factors. Newman Fairclough, the pioneer of this approach proposed three dimensions to approach CDA: (1) textual analysis at various levels; (2) analysis of discursive practice, including production, communication, and consumption of texts; and (3) social cultural analysis. As the analytical framework of sociocultural approach is specific and accessible, it has been widely employed by linguists to reveal ideologies, power, and social relations embedded in discourse.

Introduced into China in 1995, CDA attracted the attention of many Chinese scholars and in recent years was used in analyzing discourses of politics, journalism, media, education, advertisements, etc. However, it is seldom used in subcultural studies. Considering the close relations between subcultures and social cultural factors, this study attempts to apply Fairclough's sociocultural approach in discussing the subcultural discourse. 


\section{Textual Analysis of Subcultures}

The first dimension of Fairclough's approach is concerned with the subcultural texts. In the texts of the subcultural discourse, the various linguistic strategies at the textual level such as anti-language, transitivity, modality, and borrowing are used to destruct mainstream discourse and build the heterogenetic discursive system of subcultures. On lexical level, anti-language is a common linguistic strategy of subcultures. First put forward by Halliday in 1976, anti-language was defined as a variant of language or metaphorical expression of language generated by anti-societies. It was characterized by overlexicalization (proliferation of lexical expressions in a particular field), relexicalization (substitution of new words for old), and metaphorical forms. For example, hippie culture is an influential youth subculture in 1960s. The hippie slang, the specialized language of the hippies, is featured by these linguistic strategies. For instance, hippies in different contexts call each other freak, acid freak, head, acidhead, cube head, experienced, diggers, plastic hippie, flower power, flower children, flower people, young beautifuls, young beggars, young artists, youthful underground, dropouts, world revolutionary communities, emerging revolutionary generation, tribes, new bohemians, and rainbow hippies. The mainstream society is also named by hippies as the man, the establishment, the system, outdated political mechanisms, straight, and square. An important symbol for hippie culture is LSD (lysergic acid diethylamide). Hippies also use different words to refer to LSD, such as acid, cap, tab, ticket, hits, liquid, sheets, blot acid, blotter, and blots. There are also referential words for different types of drugs, such as cocaine and heroin. Various slang words help to construct the discursive system of the hippie culture and shows their central concerns. By constructing their own lexical system, the basis of the mainstream discursive system is deconstructed and a relatively isolated close subcultural discursive system is built.

On the sentence level, subcultural groups also choose particular transitivity system to represent the world through their eyes and modal forms to construct the subcultural attitudes and ideologies. Transitivity describes the relationship between participants and the roles they play in the processes described in the sentence. The processes are represented by different types of verbs and therefore there are four types of process - the verbal process, the mental process, the relational process, and the material process. For example, when describing a hippie protest against police, The San Francisco Oracle, a hippie underground press, mainly used the material processes to represent the event in an article "Flex, Reflex" in its second issue. The following Table 1 shows how the sentences are constructed in this hippie report.

Table 1

Material Process Sentences in "Flex, Reflex"

\begin{tabular}{|l|l|l|}
\hline Agency & Action verbs & Objects \\
\hline A slowly cruising squad car & Did & An angry u-turn \\
\hline Five gun barrels & Poked out & Its windows \\
\hline Another voice from within and a mumbled “ damn niggers" & & "Get off this street, boy-Now" \\
\hline $\begin{array}{l}\text { Truck-loads of bayonet wielding troops \& beef \& bullet } \\
\text { stuffed police cars }\end{array}$ & Stalked & The street \\
\hline "merry men" & Wielding & $\begin{array}{l}\text { Picket signs:-cops go home, support } \\
\text { love, \& no more curfew }\end{array}$ \\
\hline The crowed & Had swelled to & $\begin{array}{l}\text { About 200 children, hippies \& just } \\
\text { bystanders. }\end{array}$ \\
\hline A fire engine & Roared & \\
\hline $\begin{array}{l}\text { A wall of club wielding blue uniforms followed by olive } \\
\text { drab riflemen with posed bayonets }\end{array}$ & Coming & \\
\hline
\end{tabular}


(Table 1 continued)

\begin{tabular}{|l|l|l|}
\hline Agency & Action verbs & Objects \\
\hline The surprised people & Were herded down the street & \\
\hline The loudspeaker system & Began to work & \\
\hline An empty bus & Pass & \\
\hline The "great" Haight-Ashbury Police action & Ended & \\
\hline The panhandle & Packed with & $\begin{array}{l}\text { Beautiful people ecstatically costumed } \\
\text { and handing out flowers to friends and } \\
\text { FBI agents }\end{array}$ \\
\hline The FBI agents & Held & His flowers behind his back \\
\hline $\begin{array}{l}\text { Young beautifuls, young beggars and mummers, dancers } \\
\text { and singers, laughing boys and girls }\end{array}$ & Lay down & Their gentle message. Love. \\
\hline They & Had & Their world. \\
\hline Fear and tension & Subsided & \\
\hline Others & Join in & \\
\hline
\end{tabular}

Notes. Source: The San Francisco Oracle facsimile Edition Issue No. 2.

In these sentences, the agencies are the two opposite sides - the authorities and the hippie community. The authorities do not appear directly, but are represented by the police and other associated objects such as cruising squad car, gun barrel, fire engine loudspeaker system as the subjects of the actions, showing the violent nature of authorizes. At the same time, the verbs poke out, stalk, roar gave a negative presentation of the police. At the end of the report, the sentence "Young beautifuls, young beggars and mummers, dancers and singers, laughing boys and girls - soon to be outlawed - that afternoon lay down their gentle message, loud and clear. Love" cast a favorable light on the hippies and their demonstration.

On the sentence level, modality is another important discursive strategy that shows the judgments, comment, and attitude of a speaker or a writer (Richardson, 2007). The hip hop is another popular youth subculture that originated in Black neighborhood of America in late 1970s. Rap music is the most important cultural expression of hip hop youth. In the rap songs, rappers used Black grammar, which is deviant from Standard English to voice their identity as a subcultural group. The rappers used high or medium leveled modal verbs or adjuncts to express their resistance and criticism of racism and injustice, the sympathy for the blacks under discrimination and suppression. For example in the following sentences,

(1) My son said, Daddy, I don't wanna go to school

'cuz the teacher's a jerk, he must think I'm a fool. (Grandmaster Flesh, "Message")

(2) Your authority's never questioned

No-one questions you

If I hit you I'll be killed. (KRS-One, "Who Protects Us From You")

(3) Niggas definitely know what time it is

The Notorious one in full effect. (Notorious B.I.G, "Ready to Die")

In the first sentence, the modal verb "must" is used to convey the black boy's recognition of racial discrimination by the teacher In the second sentence, the adjunct "never" shows the strong criticism of the bias in favor of the white. In the third sentence, the word "definitely" shows the confidence in the black people. The modal forms construct the defiant attitudes of the rappers.

On the structural level, subcultures use various intertextual strategies to shake off the control of the mainstream ideologies and reconstruct the subcultural utopia. Intertextuality means all the texts should be 
understood in relation to other texts and to the social context. A common intertextual feature in subcultural texts is signaled by the use of borrowing. For example, inconsistent with the classic musical structure, the rap music borrows African oral tradition. African oral tradition is featured by call-response, narration, and repetition, which is widely employed by American rappers.

In the rap song "Who Protects Us From you", KRS-One uses the call-response mode:

(1) Fire! Come down fast!

You were put here to protect us, but who protects us from you?

Every time you say, "that's illegal", does it mean that's true?

[Chorus:] Un hun.

(2) There was a time when a blackman couldn't be down with your crew

[Chorus:] Can I have a job please?

Now you want all the help you can get. Scared? Well ain't that true

[Chorus:] Goddamn right. (KRS-One, "Who Protects Us From You")

In the first example, when KRS asks: "Every time you say, 'that's illegal', does it mean that's true?" the chorus respond with "Un hun". In the second example, KRS pointed out that the police feel scared because of the insufficient backup, the chorus echoed with "Goddam right", to justify the belief that the police should put the blame on themselves. Through call-response mode, the rappers connect themselves to African people, a victim of American Anglo-Saxon mainstream and establish the "other" identity that resists the racism of the mainstream culture.

On the textual level, the subcultural groups use various lexical, syntactical, and structural strategies to establish the rebellious subcultural identity, ideologies, and internal relationship and therefore resist the mainstream discursive system.

\section{Discursive Practices of Subcultural Groups}

Discursive practices are the processes involved in the production and consumption of texts. The subcultural groups have sought for the advanced medium to generate, communicate the discourse, and build the interaction within the community. Journals, music, and literature are the common communicative tools for the subcultures. For example, in 1960s, hippie activists set up a lot of hippie underground papers as their voice. The underground press served as the production and communication center of hippie discourse. Take UPS as an example. This is a non-profit organization set up by underground papers in mid 1960s to coordinate and reinforce the member papers. The UPS members increased from five in 1965 to 98 in 1969 and became the largest underground press organization. Famous underground press included San Francisco Oracle, Los Angeles Free Press, East Village Other, Avatar, Washington Free Press, etc. Although most of the hippie papers did not have a long life, their distinctive features became an important part of hippie culture and witnessed the gold time of hippies.

Music is another discursive medium of subcultural groups. For example, rap music creates the collective memory of black youth resistance. Through live performance, cassette, and MV, rap music provides different cultural experiences for hip hop members. The live performance helps build the effective bonds in community members; cassettes and CDs construct the individual experience of rap fans and MV adds the visual element and creates a real life effect. With various musical forms, American hip hop culture spread across the geographical boundaries. 
Besides journals and music, other subcultures employ literature to communicate their desires and beliefs. BL (boy's love) culture is such a female youth culture that emerged in 1970s in Japan and was introduced to China in 1990s. The BL fans create and consume male-male romance which is labeled as Danmei in Chinese. In China, BL fans prefer to call themselves "rotten girls" (a Chinese translation from Japanese for the female fans of BL). Different from hippie and hip hop culture, the Danmei texts since its birth have been written, read, and communicated on websites such as specialized literary websites, BBS, and special Danmei websites. The Internet creates more possibilities for young women regardless of their backgrounds to write BL novels, supports more interaction between the writers and readers in the process of producing BL works. Furthermore, by means of the Internet, the BL fans also participate more actively in the virtual community. Take the fans of as an example. This is a fantasy of the Gods romance published on the online literary websites Jingjiang Wenxue City in 2006, one of the biggest literary websites in China. It is found that since its online publication the fans Right Wing of Gods have written more than 200,000 comments, 450 review articles, 75 dojinshi stories related to it. Some of the fans even created its sequels, songs, comics, pictures and MV, radio drama. The active engagement of the rotten girls shows that the BL subculture has great potentials for cultural reproduction.

The three subcultures show that the subcultural practices are changing along the time. By adopting various medium, the subcultures gain more discursive space and support of the cultural expression.

\section{Social Practices of Subcultural Groups}

The discursive strategies and practices have a close relationship with the social practices of subcultural members. More often than not the subcultures are born in social transformation when the conflicts within the social structure intensify and the ideologies of mainstream society lag behind the progress of the society.

For example, the hippie culture emerged in the post WWII America, the so-called "affluent society". The economic boom ushered in the post-industrial society, which was featured by highly rigid social system and suppression of human nature. As the opinion polls and surveys then showed that alienation and sickness of the Establishment grew among young people. The alienation drove young people to seek for alternative culture that rejected the traditional values and life style and embraced the nature and the humanitarian values.

Another instance is the hip hop culture. The hip hop culture was born in 1970s, when the American economy was suffering a deep recession and the manufacturing industry declined on large scale. Manufacturing jobs moved away from urban centers to the suburban and overseas. Among all the social groups, the Black community was the most stricken. The Black youth confronted great challenges such as high unemployment rate, deteriorating education, decay of the urban facilities and most of all, the racial discrimination that permeated into everyday life. To fight against the hard realities, the black youth from the working class created hip hop, including rap music, hip hop dance, fashion, language and style to reverse their social dilemma and achieve national presence and voice against racism.

In modern China, subcultures sprout in a different social context. For example, BL culture was introduced to China in 1990s when China was reforming its economy and changed from an isolated state to a more opening environment. The young Chinese women gained more economic independence from the economic prosperity. Meanwhile, because of the expansion of higher education, they also had an increasing awareness of gender equality and more flexible view of gender characteristics. However, gender discrimination and stereotypes, which once was lashed out and weakened by the government, began to revive in the job market as 
the marketing economy was established. In producing and consuming BL works, the rotten girls challenged the traditional gender stereotypes and inequality.

The subcultural discourse is a cultural response of the youth to their social environment. In turn, it reshapes the ideologies and status quo of the mainstream. For example, the hippie discourse changes the Americans' view on the post-industrialism. Though hippie movement faded in 1970s, more and more Americans reflect on the American values that stem from post-industrialism and stress on rational knowledge over human nature. The hippies' concern about the relationship of man and the nature draws more public attention to the nature and with other social forces promotes the public's awareness of environmental protection. Another subculture, the hip hop is also a case in point. The hip hop changes the invisibility of Black youth in American society and reveals the hard realities, particularly racism plaguing the Black community. Rappers and hip hop fans therefore participate in more political activities aimed to change the sociopolitical transformation. The BL culture also brings about the social change in China. By narrating and discussing the love of beautiful young men, BL fans redefines the gender and gender disposition, changes the objectivity of female, promotes the change of public attitude towards LGBT (lesbian, gay, bisexual, and transgender) in China. The three subcultures prove that the subcultural discourses continue to negotiate with the mainstream, obtain more discourse rights for youth, and reshape the mainstream ideologies.

\section{Conclusion}

Since the mid 20th century, youth subcultures have grew and continued to extend its influence to the mainstream society. As it grows, the discursive strategies of youth subculture are diversifying and the discursive practices proliferating, revealing the enormous creativity of youth. However, no matter how its form changes, the stance of youth subculture towards mainstream power remains-deviant, playful, rebellious, and resistant. It breaks the cultural hegemony of the ruling class and voices the desire of the marginalized youth for freedom and equality. Through the critical discourse analysis of subcultural practices, it is evident that we cannot ignore the interaction of the subcultural discourse with social factors, such as class, race, and gender. Their interaction brings about momentum for renewing of the subcultural discourse and promoting the development of the youth cultures.

\section{References}

Fairclough, N. (1995a). Media discourse. London: Arnold.

Fairclough, N. (1995b). Critical discourse analysis: The critical study of language. London: Longman.

Faiclough, N., \& Wodak, R. (1997). Critical discourse analysis. In T. A. V. Dijk (Ed.), Discourse as social interaction (p. 258). London: Sage.

Fairclough, N. (2000). New labor new language? London: Routledge.

Fairclough, N. (2003). Analysing discourse: Textual analysis for social research. London: Routledge.

Haenfler, R. (2014). Subcultures the basics (p. 12). NY: Routledge.

Halliday, M. A. K. (1976). Anti-languages. In J. J. Webster (Ed.), Language and society. Beijing: Peking University.

Reisigl, M., \& Wodak, R. (2001). Discourse and discrimination: Rhetorics and racism and anti-Semitism. London: Routledge.

Richardson, J. E. (2007). Analysing newspapers: An approach from critical discourse analysis. NY: Pagrave Macmillan.

Wodak, R. (1996). Disorders of discourse. London: Longman.

Wodak, R. (2005). Fragmented identities: Redefining and recontextualizing national identity. In P. Chilton and C. Schaffner (Eds.), Politics as text and talk: Analytical approaches to political discourse (pp. 143-169). Amsterdam \& Philadelphia: John Benjamins.

Van Dijk, T. A. (1993). Elite discourse and racism. Newbury Park, CA: Sage. 
Van Dijk, T. A. (1998). Ideology: A multidisciplinary approach. London: Sage.

Van Dijk, T. A. (2001). Multidisciplinary CDA: A plea for diversity. In R. Wodak and M. Meyer (Eds.), Methods of critical discourse analysis (pp. 95-120). London: Sage. 